\author{
Bechtel Bettis, Inc. \\ Bettis Atomic Power Laboratory \\ West Mifflin, Pennsylvania \\ Materials Technology \\ Advanced Materials System Integration
}

Information Brief

TITLE:

AUTHORS:

DATE:

SIGNIFICANCE

TO THE

NR PROGRAM:
EXECUTIVE SUMMARY:
Materials for the Control Drive Mechanisms (U)

John D. Metzger, Daniel Vennetti and Kurt Koch

DEC 142005
This report addresses materials that were identified, tested and used for the Control Drive Mechanisms (CDM) for the SNAP and SP-100 space nuclear power programs. Included in the report is a description of the proposed CDM for the Prometheus Project and the status of the materials, as identified in the previous two space nuclear power programs. The materials for the CDM's were chosen to ensure the reliable, autonomous operation of the CDM's for an extended lifetime, in an adverse environment without the benefit of periodic maintenance.

The design for the Control Drive Mechanisms for the Prometheus Project did not have the opportunity to mature to the extent to consider component materials. This report documents the effort to research and document the materials that were used for the SNAP reactor systems CDM's, research and document the materials that were used for the SP-100 CDM's, identify the material issues that had been documented for the SP-100 CDM's, identify material differences between the SP-100 CDM's and the proposed Project Prometheus CDM's, and document the current status of the CDM materials.

The CDM's for the SNAP Program evolved over the lifetime of the program to a design that could meet their design requirements. This program had the benefit of flying a reactor power system and obtaining operational experience; however, the design lifetime for the system was much less (1.15 years, 10,000 hours) than the design lifetimes for the SP-100 Program (7 years) and the Prometheus Project (12-15 years). Another major difference between the SNAP control assemblies and those of the SP-100 and Prometheus is that SNAP utilized extemal rotating control drums and SP-100/Prometheus had external sliding reflectors.

At the SP-100 program's termination, the control drive assembly (CDA) development team believed that it had demonstrated that the technology status was adequate for a 3-year operating lifetime and 5-year mission design $\left(20-\mathrm{kW}_{\mathrm{e}}\right.$ design), but had not demonstrated the technology to support a mission that required operation for seven years and a 10 -year mission (the $100-\mathrm{kW}_{\mathrm{e}}$ design). The SP-100 CDA development team identified material issues that needed to be addressed prior to achieving the technology status necessary to support the 100 $\mathrm{kW}_{\mathrm{e}}$ system's seven-year operational lifetime. These issues included the 
acquisition and delivery of uncommon materials and bearings, the development of advanced materials, the demonstration of adequate lifetime of bearings and bearing races of dissimilar materials under operating conditions, control of the metallurgy and processing of materials to ensure dimensional stability, and the choice of a material for the magnet wire coil bobbins that is adequate for the system's operating conditions.

The CDM for the Prometheus Project is based on the SP-100 CDM concept. The design uses linear motion actuation to move the sliding reflectors axially towards and away from the reactor. This linear motion is generated by coupling a stepper motor, which provides rotational motion, to a ball screw, which converts the rotational motion into translational motion. A number of small variations to the SP-100 design were incorporated into the Prometheus design for more efficient and problem-free operation. The primary differences between the two designs, that would potentially impact material choices, were that the Prometheus Project design proposed the use of a magnetic hysteresis brake instead of a electromagnetic brake, the use of a magnetostrictive transducer to sense the leadscrew position verses a linear variable differential transformer (LVDT), and the incorporation of dual flexure joints on the reflector driveline instead of splined ball in socket joints.

An investigation of materials specified for the SP-100 CDM, which the Prometheus conceptual design was predicated on, revealed that many of the materials that were new and difficult to acquire in the 1980's and early 1990's appear to be more readily available. Often, these materials have evolved to where various forms, for example different alloys, have been developed to meet user requirements. These statements apply to, for example, HIPERCO and STELLITE alloys, carbon-carbon components, and ceramic materials. Operational experience has also evolved from the application of these materials under a variety of conditions. Despite the advances in materials and the operational experience gained with these materials over the past 10 to 15 years, the testing and demonstration of a CDM in the operating conditions of a space nuclear power system would be required to ensure reliable operation. With the evolution of materials, an assessment and identification of the best materials to meet the design requirements would be necessary when the effort is reinitiated in the future. 
Significance to the NR Program

Table of Contents

Executive Summary 1

Table of Contents 1

Table of Figures 3

Table of Tables. 4

1.0 Introduction 4

2.0 Background. 5

2.1 SNAP Program Control Drive Mechanism. 6

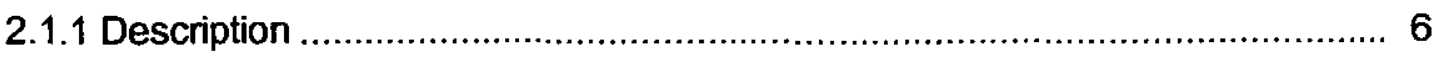

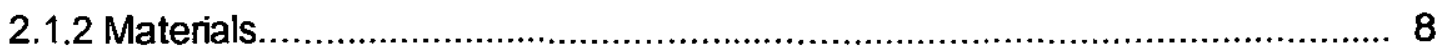

2.1.3 SNAP Program References.............................................................. 8

2.2 SP-100 Program Control Drive Mechanisms...................................................... 9

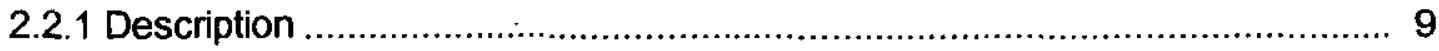

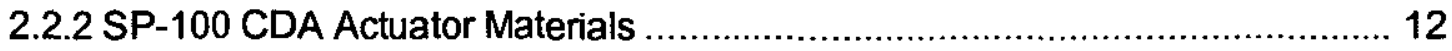

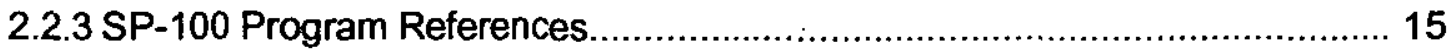

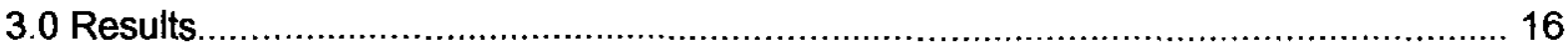

3.1 Project Prometheus Control Drive Mechanism ....................................................... 16

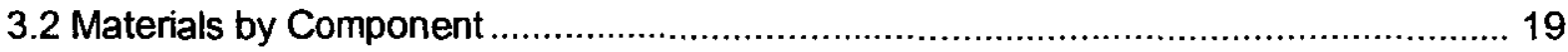

3.2.1 SP-100 Common Materials for the SRDA and the CRDA ........................... 19

3.2.2 Materials For Project Prometheus CDM ................................................ 28

3.2.3 CDM Material Development Issues ....................................................... 29

3.2.3.1 SP-100 Control Drive Assemblies - Lessons Leamed ,.................... 29

3.2.3.2 Project Prometheus CDM Material Issues....................................... 31

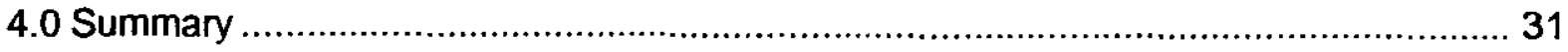


B-MT(AMSI)-43

Page 4

Table of Figures

Figure 1: Project Prometheus Reactor Concept Depicting Sliding Reflectors ................... 5

Figure 2: SNAP 8 Control Drum Drive System (Ref. 3) ........................................... 7

Figure 3: S8DRM-1, SNAP 8 Indirect Drive, Solid Rotor Actuator (Ref. 3) ...................... 7

Figure 4: SP-100 GFS Safety Rod Drive Assembly (Ref. 8) .................................. 9

Figure 5: SP-100 Reactor Control Drive Assembly (Ref. 8) ........................................ 11

Figure 6: SP-100, 20 kW , Dual Function Control Drive Assembly (Ref. 8) ...................... 12

Figure 7: Project Prometheus CDM (Ref. 21) ..................................................... 17

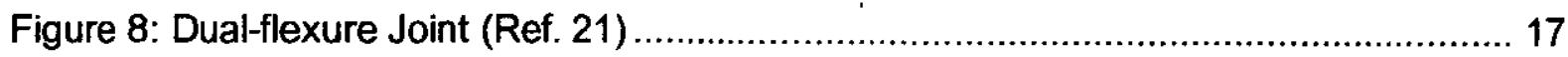

\section{Table of Tables}

Table 1: Common Materials for SP-100 SRDA and RCDA ..................................... 13

Table 2: Materials Specific for the SP-100 SRDA ..................................................... 14

Table 3: Materials Specific for the SP-100 RCDA ................................................. 14

Table 4: Description of Common Materials for the SP-100 SRDA and RCDA ................... 23

Table 5: Description of Materials Specific for the SP-100 SRDA ................................... 27

Table 6: Description of Materials Specific for the SP-100 RCDA ................................... 28 


\subsection{INTRODUCTION}

The Project Prometheus reactor design controls core reactivity using external reflectors. Various reflector configurations were evaluated, including sliding reflectors and rotating drum reflectors. The sliding reflector concept is depicted in Figure 1, and consists of a fixed reflector ring and multiple moving segments. To increase reactivity, the movable segments are moved into position to surround the fueled region of the core. Mechanical design work on the reflector system was in the early stages. The mounting concept shown in Figure 1 includes a support ring around the vessel to provide attachment for the slide rails, drive rods and other associated hardware. The

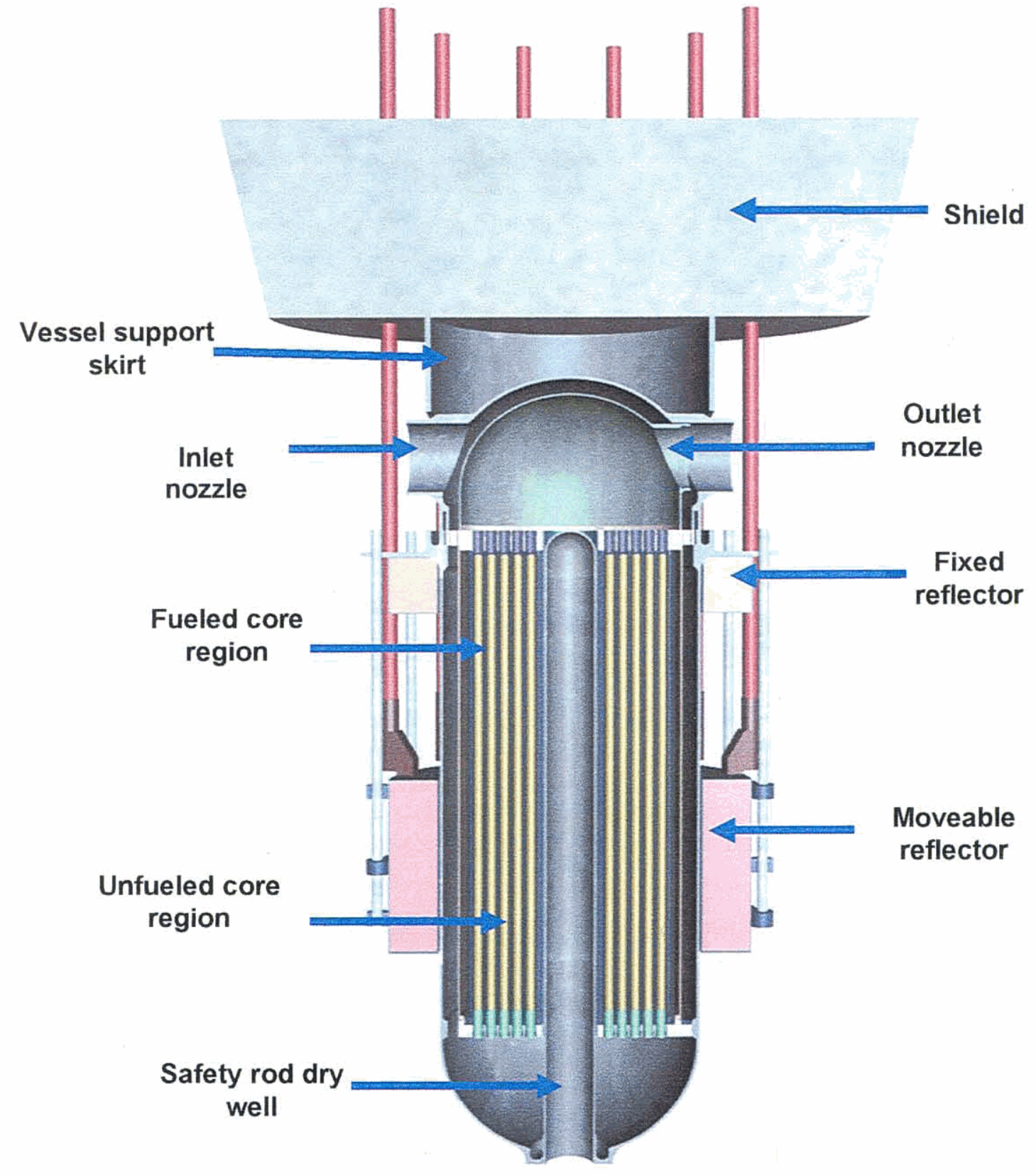

Figure 1: Project Prometheus Reactor Concept Depicting Sliding Reflectors. 
B-MT(AMSI)-43

Page 6

reflectors are moved by electric control drive mechanisms (CDM's). It was envisioned that the CDM's would be mounted on the back side of the radiation shield. The Prometheus reactor design also included safety rods that were inserted for launch, prior to operation, and shutdown. The safety rod arrangement, and its drives, was not specified because the reactor design was not finalized when the program was terminated.

\subsection{BACKGROUND}

\subsection{SNAP Program Control Drive Mechanism}

\subsubsection{Description}

The SNAP 2, 10a and 8 nuclear power systems were designed to provide electrical power for space vehicles. All the SNAP reactors were liquid-metal cooled (NaK) with uranium-zirconium hydride fuel. The SNAP 2 and 10a reactor systems were integrated with a thermoelectric power conversion system and the SNAP 8 reactors were coupled to a mercury Rankine power conversion system. The reactors were all controlled by rotating, external beryllium reflectors. The control drum drive mechanical system included the actuator, bearings and gears. A flexible coupling was also investigated for the SNAP 8 system.

To put the SNAP systems into a developmental timeline, the criticality dates and shutdown dates for these systems were as follows:

System

SNAP 2 Experimental

SNAP 2 Developmental

SNAP 8 Experimental

SNAP 10a FS-3

SNAP 10a FS-4

SNAP 8 Developmental
Critcal Date

19 September 1959

April 1961

May 1963

January 1965

3 April 1965 - launch

4 April 1965 - power operation

June 1968

\author{
Shutdown Date \\ 19 November 1960 \\ December 1962 \\ 15 April 1965 \\ 16 March 1966 \\ 16 May 1965
}

December 1969

The CDM for the SNAP 8 Developmental reactor was based upon the development and successful operation of the CDM's for the previous SNAP systems. Figure 2 shows the SNAP 8 Control Drum Drive System. Three electromagnetic actuators were developed for the SNAP 8 Program: two indirect-drive designs and a direct-drive backup design. All three models were direct-current, variable-reluctance actuators that drove the control.drums, either directly or indirectly, with a gear train.

The SNAP 10a actuator was the baseline design for the SNAP 8 (designated S8DRM-1) actuators, Figure 3. Both designs were direct-current, variable-reluctance actuators that rotated the drums in precise, discrete steps. With the power off the rotor and shaft were prevented from rotating by a spring-loaded brake. With the power on the energized brake solenoid compressed the brake spring and released the brake. At the same time, the stator coils were also energized in sequence to produce rotation. The design incorporated a permanent-magnet, rotor actuator that consisted of a stepper motor and a brake. The motor and brake consisted of a stator with eight salient poles; associated winding and encapsulation system; a rotor which consisted of a permanent magnet, slotted end caps, shaft and journals; and two end bell assemblies with bearings. The actuator motor could operate in either direction and each pulse resulted in a step of $1.8^{\circ}$. 
The differences between the SNAP 10a actuator and the SNAP 8 actuator were due to the more stringent design and environmental criteria for the SNAP 8 system. These differences included higher temperatures, longer life, more torque, and greater shock and vibration. This led to a design that was an extension of the SNAP 10a actuator technology. To accommodate these increased requirements the SNAP 8 design included the following: a larger brake coil to allow continuous operation; a larger rotor and brake to provide more torque; an improved insulation system to allow operation at increased temperatures; Inconel- $X$ instead of titanium for structural components; and the use of a one-piece non-permanent magnet verses a three-piece permanent magnet rotor.

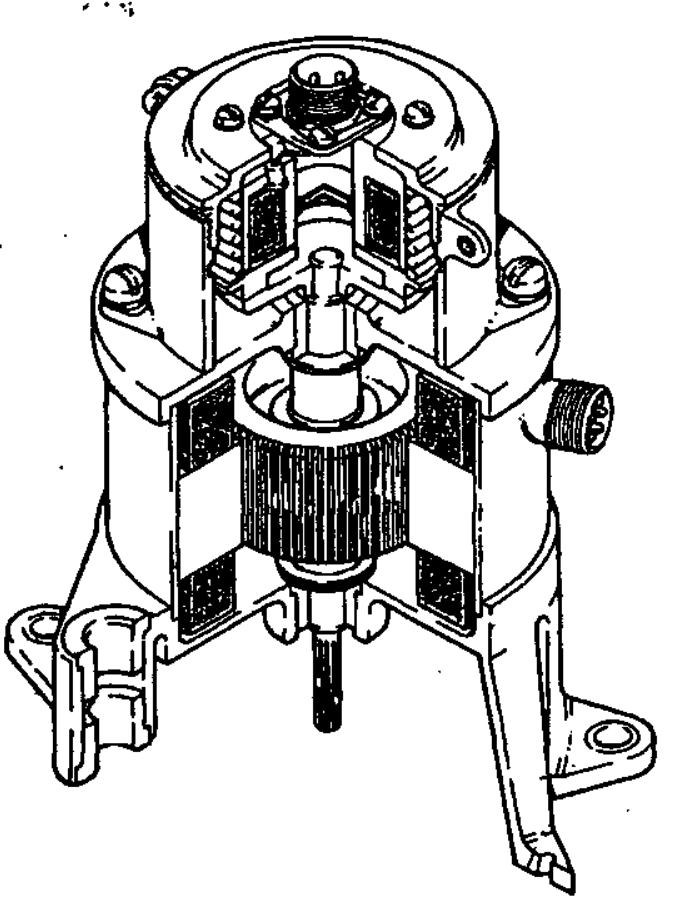

Figure 3: S8DRM-1, SNAP 8 Indirect Drive, Solid Rotor Actuator (Ref. 3)
The S8DRM-1 actuator was the SNAP 8 baseline actuator; however, due to the launch and operational experience of the SNAP 10a, a more robust design was investigated, designated the S8DS actuator. The modifications included in this design were the incorporation of a single material for both structural and magnetic components: Hiperco 27, an iron-cobalt alloy that maintains it's structural and magnetic properties at higher temperatures and eliminates the problems associated with different coefficients of thermal expansion between different materials. Also, the stator coils were wound using a wet winding technique.

The main concem for the selection of the gear train, bearings and gears was to find a combination of materials and lubricants that would prevent selfwelding and reduce friction between the components when exposed to the operating and environmental conditions of the system. 


\subsubsection{Materials}

The SNAP Program recognized the importance of the correct selection of materials for the CDM's to accommodate stringent operating and environmental conditions. The following paragraphs outline the materials that were chosen by the program for the CDM's. SNAP 8 materials are covered since it was the system that was the last in development and had the most stringent requirements.

Springs - Programmatic parametric temperature and radiation effects on radiation performance indicated that the best material for the springs was Renè 41 .

Structure and Magnetic Components - The program initially considered Inconel-X, titanium, and stainless steel for the structural components of the CDM's; however, as the program progressed the elimination of differential expansion was identified as being important. To this end a decision was made to construct the structural components of the same material as the rotor and stator poles. The material chosen was Hiperco-27, a cobalt-iron alloy. This material was selected for the frame, end bells, shaft and magnetic circuit and was used as the magnetic material in place of chromium-coated silicon-iron electrical grade steel. It exhibited better magnetic properties at high temperatures $(>800 \mathrm{~K})$, had good corrosion resistance and good workability.

Stator Winding - The stator winding consisted of glass-covered, chrome-plated copper wire with encapsulant. The brake winding incorporated the same material as the stator winding, but was wet wound. The insulation used for the encapsulation PBX, a solid silica, alumina and chromium oxide in dilute phosphoric acid. When cured, this mixture resulted in molecular bonded $\mathrm{SiO}_{2}$ and alumina $\left(\mathrm{Al}_{2} \mathrm{O}_{3}\right)$ coating. Atomics International developed a proprietary wet-wound encapsulant, SAP II, which is not described in the reports.

Bearings, Shaft and Gears - The CDM actuator bearings were mechanical carbon-graphite in interfacing with alumina-coated metals for primary friction surfaces. The bearings were lubricated with sodium-silicate bonded dry-film lubricants. The control-drum bearing/shaft assembly consisted of an alumina-coated Inconel-X shaft, K-162B (sintered TiC+Ni) bushing, aluminacoated Inconel- $X$ ball bearings and socket. The pinion and the gear were Inconel- $X$ to Inconel- $X$ with bonded dry-film lubricant coatings. The gears for the SNAP 2 and SNAP 8 system were within the shadow cone of the shield. The gears for the SNAP 10A were partially outside of the shadow of the shield, and thus, the gears and pinion were made of titanium alloys due of titanium's low neutron scatter cross-section.

Friction and Brake Surfaces - The brake material in the actuators was alumina and chrome. Other options considered were carbon and titanium or alumina and Inconel-X.

\subsubsection{SNAP Program References}

Title

1. The Development Philosophy for SNAP Mechanisms

2. SNAP 8 Control Drum Actuators

3. SNAP Reactor Control-Drum Drive
Author

O.P. Steele, III

S. Giles \& A.A. Marcus

L.G. Kellogg
Source

$3^{\text {rd }}$ Aerospace Mechanism Symposium

NAA-SR-9645, dated 12/15/64 (OSTI ID 19123, Space Nuclear Fission Power)

NAA-SR-9615, dated $8 / 24 / 64$ 


\subsection{SP-100 Program Control Drive Mechanisms}

\subsubsection{Description}

The CDM's (also, referred to as Control Drive Assembly, CDA) for the SP-100 were the only active components in the entire SP-100 power system. The $100 \mathrm{~kW}$. SP-100 had separate drives for both the in-core safety rods and the external reactor control, sliding reflector panels. The 20 $\mathrm{kW}_{\mathrm{a}}$ system had one drive assembly for both the safety and the control function; i.e., since the

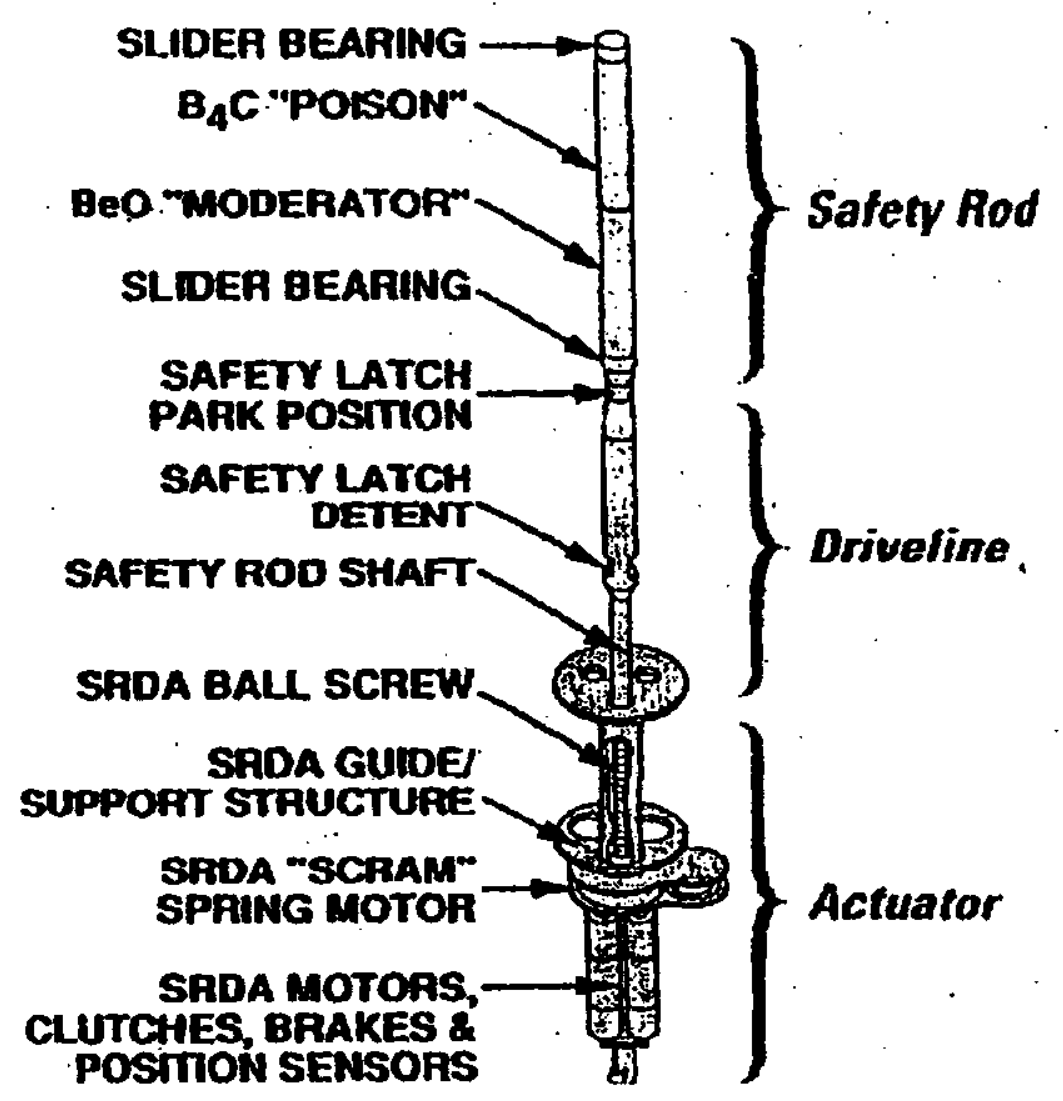

Figure 4: SP-100 GFS Safety Rod Drive Assembly (Ref. 8) system was small it was controlled by in-core control elements. The technology developed for the CDM for the $20 \mathrm{~kW}$. was demonstrated to be adequate for the three-year operating and five-year mission lifetime of the system. The CDM technology was not demonstrated to be adequate for the seven-year operating and ten-year mission lifetime for the $100 \mathrm{~kW}_{\mathrm{e}}$ system.

The Safety Rod Drive Assembly (SRDA), Figure 4, was used for shutdown only and not power adjustment. The safety rods were inserted for reactor transportation and launch safety shutdown, onorbit shutdown, and end-ofmission permanent shutdown. The SRDA consisted of 3 internal safety rods driven by a single step motor. Two motors were incorporated to provide redundancy. The SRDA consists of the following

components:

- Drive Motor - The drive motor was a three-phase, variable-reluctance, step motor. The motor utilized bobbin wound coils which were best suited for the high-temperature insulation system.

- Clutches and Brakes - The clutches and brakes included the drive clutch and brake, the latch clutch and brake, and the scram clutch. The clutches and brakes were all electromagnetic devices with springs opposing the magnetic attraction. The clutches and brakes were either totally engaged or disengaged.

- Drive Clutch - The drive clutch carried the motor torque when driving the safety rods and carried the scram spring torque when holding the safety rod in the operating position. The drive clutch required power to be engaged. 
- Drive Brake - The scram spring reacted against the drive brake. The drive brake was engaged by spring force and required power to be disengaged.

- Latch Clutch - The latch clutch connected the motor to the rotating guide tube and required power to be engaged.

- Latch Brake - The latch brake held the guide tube and safety rod in the proper orientation while the safety rod was traversing out of the latch position

- Scram Spring - The scram spring was a constant torque spring motor connected to the ball nut. The torque was carried through the scram clutch, the gear train, drive clutch and was held by the drive brake. A release of either the scram clutch or the drive clutch allowed the spring motor to unwind, driving the ball nut and moving the safety rods to the shutdown position.

- Guide Tube - The ball screw traversed through and was keyed to a guide tube. The guide tube was bearing-mounted to the support structure and was geared to the latch end of the drive assembly. The keying was achieved by rollers on the ball screw traversing in slots in the guide tube.

- Position Sensors - Position sensors were used to detect the safety rod at its end of travel positions; i.e., at its most reactive and it's least reactive positions.

- Ball Bearings - The SRDA motor-clutch-brake consisted of three separate shafts in series supported by ball bearings. The ball bearings were of conventional design.

- Actuator Gears - SRDA motor-clutch-brake and SRDA spring motor were connected to the safety rod drive train by a ball screw and ball nut assembly and a ball nut drive gear set.

- Slider Bearings - The slider bearing acted as the only contact surface between the safety rod and the reactor vessel.

The Reflector Control Drive Assemblies (RCDA), Figure 5, were used for power adjustment (reactor neutronics, thus temperature). The RCDA consisted of twelve reflector panels driven by twelve identical mechanisms. Each reflector panel had its own drive assembly consisting of two motor drive units for redundancy. The RCDA consist of the following components:

- Hollow Shaft Step Motor - The motor was a three-phase, variable reluctance, step motor. The three stator coils were double wound for redundancy; either coil set would produce enough torque to drive the reflector. The motor motion was transmitted directly to a ball nut, which tumed against the lead screw and translated the rotation to linear motion.

- Hollow Shaft Brake - An electromagnetic brake was attached to the forward end of the motor shaft. It also had dual, independent coils. Energizing either brake coils released the brake and allowed the motor to run. De-energizing the brake coil applied the brake, locking the motors rotation.

- Ball Screw - The RCDA converted the motor shaft rotation into fore-aft linear motion with a ball screw and nut arrangement.

- Articulated PushRod - Attached to the forward end of the ball screw was a rod that penetrated the radiation shield and was attached to the reflector. The pushrod was articulated at two locations to accommodate thermal expansion of the reactor and shield.

- Guide Rails - The guard rails provided guideways for the twelve reflectors to slide on. They were rigid tubular members designed to provide support to the reflectors during periods of high loading; e.g., launch and postulated inadvertent re-entry.. 


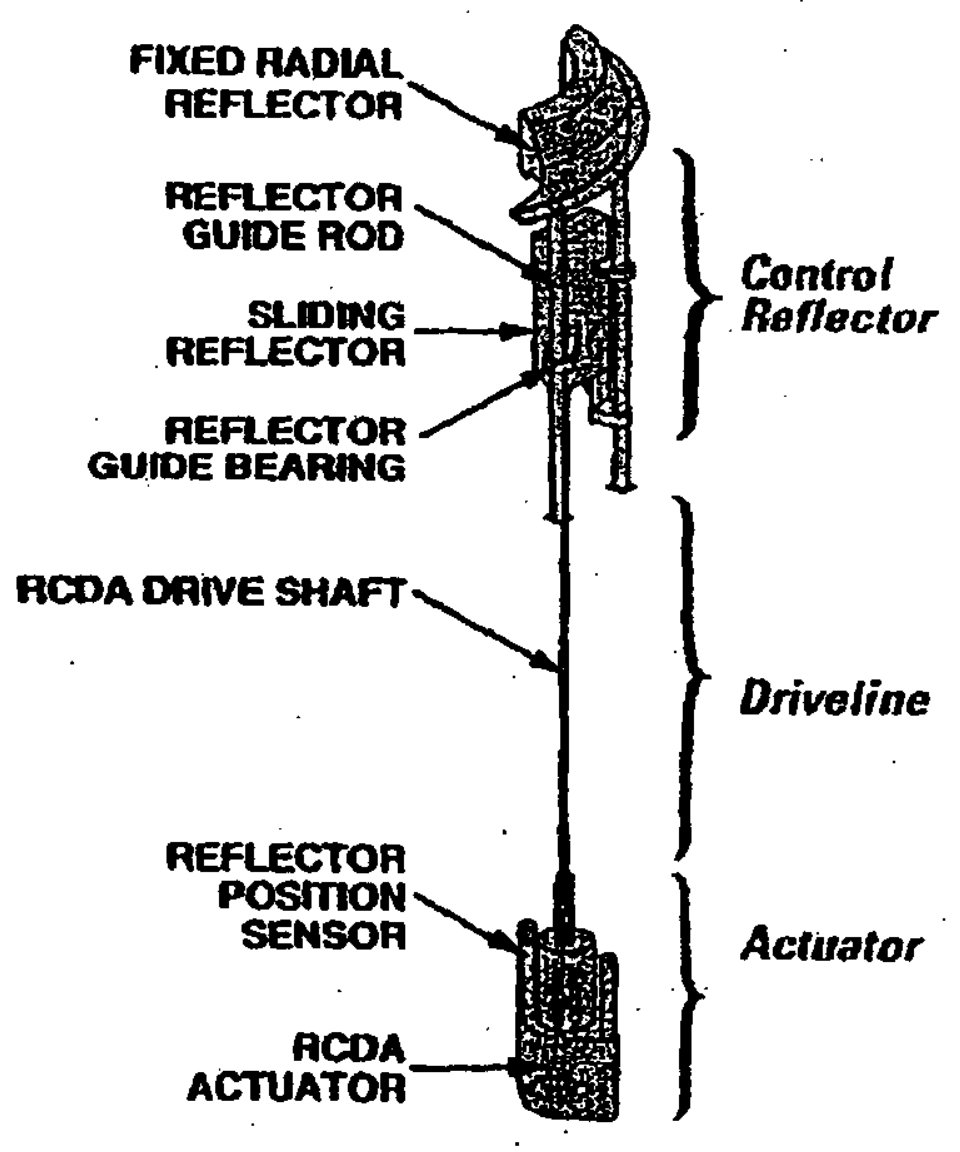

Figure 5: SP-100 Reflector Control Drive Assembly (Ref. 8)

- Guide Bearings - Each reflector was suspended on three bearings from the adjacent guiderails. The bearings were arranged so that each reflector moved independently of the adjacent reflectors, even though they share guiderails.

- Position Sensor - The RCDA position sensor provided continuous measurement of each reflector element. The position sensor was necessary for the restart of the reactor after shutdown. The neutron monitors had approximately a one-year lifetime, after which, the reactor restart and operation was dependant upon the reflector position and reactor temperature sensors. The reflector position sensor responds more quickly than the temperature sensors, and thus, their accuracy was important for the reliable operation of the reactor.

- Spherical Self-Aligning Bearing - The spherical self-aligning buṣhing was originally developed to secure and position the drive shaft and hinged reflector assembly. When the SP-100 program changed to a sliding reflector the spherical self-aligning bearing was selected as a bushing type device for the reflector element guiderails.

The $20 \mathrm{~kW}$. SP-100 system had a Dual Function Control Drive Assembly (DFCDA), Figure 5. Due to the smaller size of the $20 \mathrm{~kW}$. system reactor, with respect to the size of the $100 \mathrm{~kW}$. system reactor, the control of the reactor was accomplished solely from within the core; i.e., the safety and control function was accomplished by the same drive assembly. This resulted in the potential for a common-mode failure. The DFCDA was based upon the SRDA design. The 
DFCDA required continuous position measurement. A Linear Variable Differential Transformer (LVDT) was developed and manufactured for this purpose.

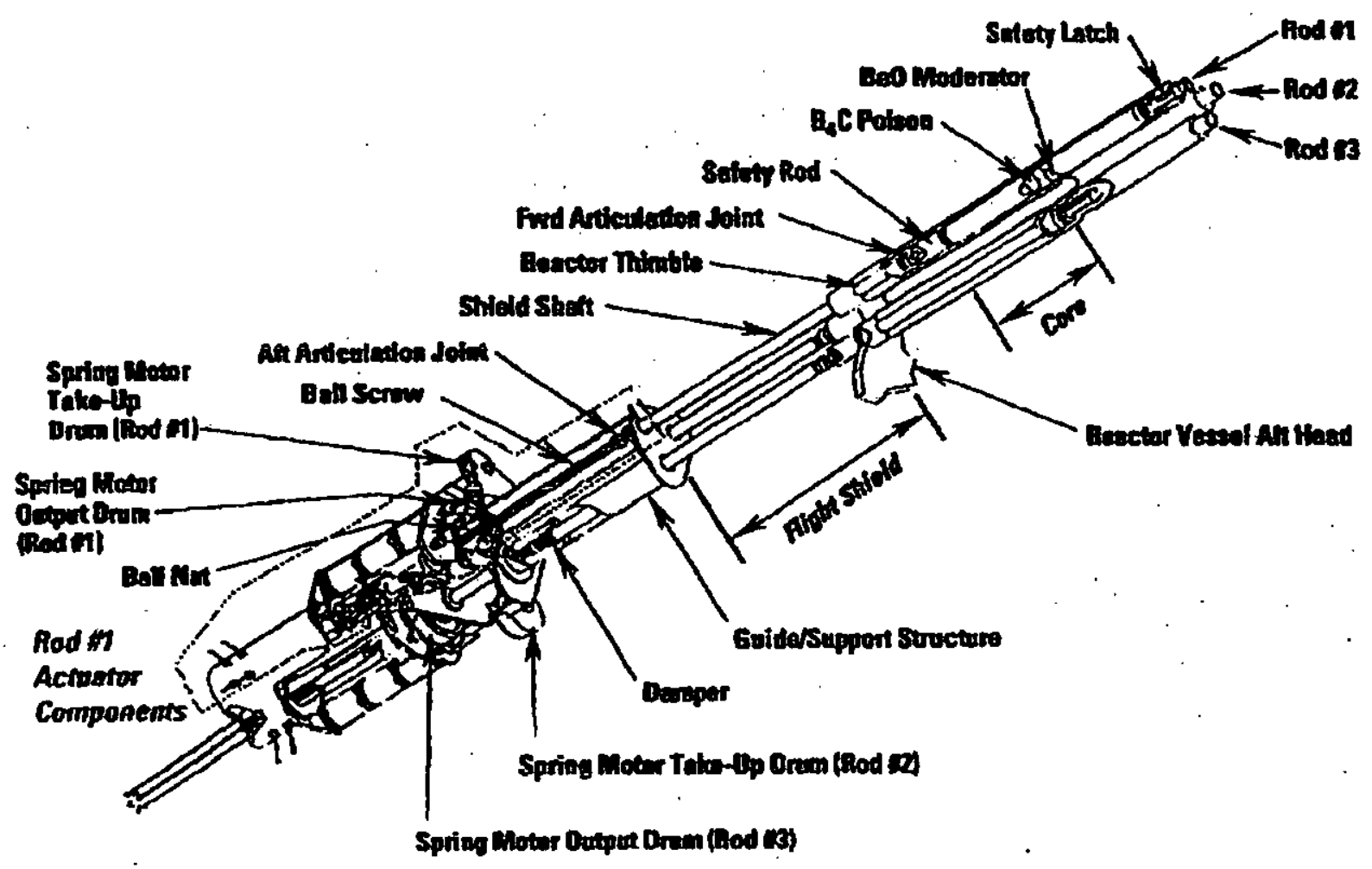

Figure 6: SP-100, $20 \mathrm{~kW}$, Dual Function Control Drive Assembly (Ref. 8)

\subsubsection{SP-100 Control Rod Drive Assembly Materials}

Much of the material and component technology were common to the actuator subassemblies for both the RCDA and the SRDA. The common materials for the SRDA and the RCDA motor, clutch, brake and position sensor are listed in the Table 1. Materials specific for the SP-100 SRDA are listed in Table 2, and the materials specific for the RCDA are listed in Table 3. 


\begin{tabular}{|c|c|}
\hline Part & Material \\
\hline \multicolumn{2}{|l|}{ Coil } \\
\hline Magnet Wire & Stainless steel clad copper w/a ceramic insulation \\
\hline Bobbin & $\begin{array}{l}\text { MACORTM (Coming)-machinable glass ceramic, mica crystals } \\
\text { embedded in a glass matrix with major constituents of } \mathrm{SiO}_{2} \text {, } \\
\mathrm{Al}_{2} \mathrm{O}_{3}, \mathrm{MgO}, \mathrm{K}_{2} \mathrm{O}\end{array}$ \\
\hline Potting & CERANACAST 584 (Aremco) - major constituent MgO \\
\hline & $\begin{array}{l}\text { ALCAL (California Fine Wire) - } \mathrm{SiO}_{3}, \mathrm{Al}_{2} \mathrm{O}_{3} \text { with organic binder } \\
\text { TECSIL (Intec, inc.) - } \mathrm{SiO}_{3} \text { (no binder) }\end{array}$ \\
\hline \multicolumn{2}{|l|}{ Magnetic Materials } \\
\hline Lamination & HIPERCO Sheet \\
\hline $\begin{array}{l}\text { Machine Magnetic Flux Path } \\
\text { Structures }\end{array}$ & HIPERCO Bar \\
\hline Brake \& Clutch Faces & Titanium Alloy or High Nickel Alloy \\
\hline Gears & Titanium Alloy \\
\hline Ball Crew and Ball Nut & Inconel 718 \\
\hline Balls for Ball Screw and Ball Nut & Tungsten Carbide \\
\hline Structure & C-C Composite and Titanium Alloy \\
\hline Hardening Coating & Titanium Nitride \\
\hline Dry Film Lubricant/Anti-Seize & $\mathrm{MoS}_{2}$ \\
\hline Fasteners & Inconel or Stainless Steel \\
\hline Springs & High Nickel Alloy; e.g., RENE'41, Inconel 750, Inconel 718 \\
\hline Bearings & Stellite and Silicon Nitride \\
\hline
\end{tabular}

Table 1: Common Materials for SP-100 SRDA and RCDA

\begin{tabular}{|l|l|}
\hline Part & Material \\
\hline Safety Rod Tubular Structure & PWC-11 or Nb-1Zr \\
\hline Slider Bearing Surfaces & CVD or Plasma Spray ZrC or HfC \\
\hline Reactor Vessel Thimble Interface & Carbide Coated Nb-1Zr or Mo-41Re \\
\hline Nuclear Poison & Boron Carbide \\
\hline Nuclear Poison to Clad Barrier & Mo Foil \\
\hline Nuclear Moderator/Reflector & Beryllium Oxide \\
\hline Shielding Follower Section & $\begin{array}{l}\text { Filled w/ Shield Materials Comparable to Flight Shield at Same } \\
\text { Station Position }\end{array}$ \\
\hline Support/Spacer Structure within S.R. & Titanium Honeycomb \\
\hline Safety Latch & \\
\hline
\end{tabular}


B-MT(AMSI)-43

Page 14

\begin{tabular}{|l|l|}
\hline Lock Bars & PWC-11 or Nb-1Zr \\
Springs & ASTAR 811C \\
Latch Housing & PWC-11 or Nb-1Zr \\
Latch Assembly Align. Pins & ASTAR 811C \\
Contact/Guidance Surfaces & ZrC or HFC \\
\hline $\begin{array}{c}\text { Separation Joints } \\
\text { Springs In/Aft Flight Shield \& } \\
\text { Structural Components }\end{array}$ & High Nickel Alloy; e.g., RENE'41, Inconel 750, Inconel 718 \\
Coatings & Nitride \\
Lubricant/Anti-Seize & MoS 2 \\
\hline
\end{tabular}

Table 2: Materials Specific for the SP-100 SRDA

\begin{tabular}{|l|l|}
\hline Part & Material \\
\hline $\begin{array}{l}\text { Reflector Guide/Positioning } \\
\text { Guide Rods }\end{array}$ & $\mathrm{C}-\mathrm{C}$ Composite or Ta-10W \\
Guide Rod Surface Coating & $\mathrm{Al}_{2} \mathrm{O}_{3}$ (for Ta-10W) \\
$\begin{array}{l}\text { Self-Aligning Guide Bearing } \\
\text { Insert }\end{array}$ & $\mathrm{P}-5$ Carbon-Graphite \\
Bearing Insert Housing & $\mathrm{C}-\mathrm{C}$ Composite or Ta-10W \\
$\begin{array}{l}\text { Bearing Insert Housing } \\
\text { Surface Coating } \\
\text { Structural Brackets/Supports } \\
\text { Fasteners }\end{array}$ & $\mathrm{Al}_{2} \mathrm{O}_{3}$ (for Ta-10W) \\
$\begin{array}{l}\text { Push Rods } \\
\text { Push Rod } \\
\text { Bearings/Articulation Joint }\end{array}$ & $\mathrm{Ta}-10 \mathrm{~W}$ \\
\hline
\end{tabular}

Table 3: Materials Specific for the SP-100 RCDA.

Specific References for the SP-100 CRDA materials:

Reference 8: SP-100 Technical Summary Report, Vol. II - Technical Report Reference 17: SP-100 Ground Engineering System Project Annual Technical Progress Report October 1991 through September 1992 


\subsubsection{SP-100 Program References}

Title

4. SP-100, A Flexible Technology for Space Power from 10's to 100's of KWe

5. SP-100 Control Drive Assemblies - Lessons Leamed

6. Safety Rod Drive Assembly Document Requirements and Design Description

7. SP-100 Technical Summary Report, Vol. I - Executive Summary

8. SP-100 Technical Summary Report, Vol. II - Technical Report

9. SP-100 Technical Summary Report, Vol. III - Bibliography

10. Road Map to SP-100 Control Drive Assembly information

11. SP-100 Control Drive Actuator Design

12. Dual Function Control Drive Assembly Conceptual Design

13. Control Drive Assembly MotorBrake Test

14. SRDA Motor-C̣lutches-Brakes Test

15. Control Drive Assembly Actuator Subassembly Development Test Report

16. SP-100 Ground Engineering System Project Annual Technical Progress Report October 1990 through September 1991

17. SP-100 Ground Engineering System Project Annual Technical Progress Report October 1991
Author

P.R. Pluta, M.A. Smith

\& D.N. Matteo

J.D. Lazanus

T.E. Gleason

J.D. Lazarus

G.V. Brynsvold

J.D. Lazarus

T.E. Gleason

A.W. Dalcher \& T.E. Gleason

JPL D-11818-Vol. II, dated 9/94

JPL D-11818-Vol. III, dated 9/94

DOE/SF/16006-T1218;

MMAS/PIR-1205, dated 6/8/94 (sent 3/30/94) (OSTI ID 17185, Space Nuclear Fission Power)

GE Aerospace Spec. No. 23A3225, Rev. 2, dated 11/4/93

DOE/SF/16006-T1066, dated 2/26/93

DOE/SF/16006-

T1088;MMAS/PIR-1123, dated 6/3/93 (OSTI ID 17411, Space Nuclear Fission Power)

DOE/SF/16006T1089;MMAS/PIR-1124, dated 6/29/93 (OSTI ID 17412, Space Nuclear Fission Power)

DOE/SF/16006T1179;MMAS/PIR-1167, dated 3/30/94 (OSTI ID 17152, Space Nuclear Fission Power)

DOE/NBM-1091; CDRL-M-028, dated 2/12/92 (OSTI ID 17078, Space Nuclear Fission Power)

DOE/NBM-10921; CDRL-M-028, dated 2/1/93 (OSTI ID 17456, Space Nuclear Fission Power) 
B-MT(AMSI)-43

Page 16

through September 1992

18. Solid Lubricant Self-Welding Testing for Control Drive Assembly Lifetime Predictions

19. The Static and Kinetic Friction Measurements of Control Drive Assembly Hard-Surface Coatings in a High-Temperature/Ultra-High Vacuum Environment

20. Control Drive Assembly Slider Bearing Development Test: Final Report

\author{
G.B.A. Schuster
}

G. Schuster

A. W. Dalcher
DOE/SF/16006-T1189; MMAS/PIR-1176, dated 2/8/94 (OSTI ID 17258, Space Nuclear Fission Power)

DOE/SF/16006T1188;MMAS/PIR-1175, dated 3/1/94 (OSTI ID 17158, Space Nuclear Fission Power)

DOE/SF/16006T1088;MMAS/PIR-1180, dated 12/30/93 (OSTI ID 17310, Space Nuclear Fission Power)

\subsection{RESULTS}

\subsection{Project Prometheus Control Drive Mechanism}

The reactor and control element designs were continuously changing up until the Prometheus Project came to a close, which resulted in a CDM design that was never well defined. A drawing of the latest version of the Prometheus CDM is shown in Figure 7. The CDM for the Prometheus Project is based on the SP-100 RCDA concept described in Section 2.2.1.

The design uses linear motion actuation to move the sliding reflectors axially towards and away from the reactor. This linear motion is generated by coupling a stepper motor, which provides rotational motion, to a ball screw, which converts the rotational motion into translational motion. A number of small variations to the SP-100 design were incorporated into the Prometheus design for more efficient and problem-free operation. The primary differences between the two designs deal with the brake system, the position indicator sensor, the drive joints, the stepper motor internals, and the order of components within the CDM.

While the brake system of the SP-100 relied on an electromagnetic brake, it was determined that an altemate brake system would be evaluated for the Prometheus brake. The electromagnetic brake of the SP-100 depended on physical contact of components to provide the braking force. This resulted in concems associated with potential wear of moving parts and the possibility of self welding. Because a hysteresis brake has no contact of moving parts, it was considered that this may be a better option for the Prometheus design. The hysteresis brake uses two magnets of different composition (samarium/cobalt and alnico) to provide the braking force. When the two magnets, which are in close proximity and are moved relative to each other, a resistive force increases rapidly and then remains constant as motion continues. After the driving motion stops, the magnets have a natural tendency to spring back the same short distance that had been traveled to increase the force from zero to maximum. The one drawback to the hysteresis brake is that there is always resistive force acting to counteract movement, which means that the motor must have enough torque to overcome the brake while it moves the load. However, because it requires no contact of moving parts and should not experience any wear or self welding, it was decided that this would be an option to consider for the Prometheus design. 

The next difference between the SP-100 and the Prometheus CDM is in the method that is used for axial position sensing of the leadscrew. From the SP-100 design, two redundant LVDT's were used for determining position. These LVDT's needed to be roughly three times longer than the stroke of the leadscrew. For the SP-100 design, the stroke was only $11.4 \mathrm{~cm}$, which made the LVDT a viable option. However, with the length of the Prometheus stroke set to be about $46 \mathrm{~cm}$, the expected length of the LVDT makes this a very impractical method of position sensing. With this in mind, a different means of sensing position was investigated. The latest Prometheus CDM design recommended using a magnetostrictive transducer to sense the leadscrew position. The magnetostrictive device basically consists of a transducer, a guide wire, and a magnet. The transducer is mounted to the CDM structure, while the guide wire runs through the hollow leadscrew which has a magnet mounted on the end. When the transducer sends an acoustic wave through the guide wire, the wave enters the magnetic field at the end of the leadscrew and another wave is reflected back to the transducer. With the wave travel time measured, the distance to the magnet can be easily determined. The magnetostrictive device is an attractive option because it adds only a little bit of length to the CDM, while still providing accurate and repeatable position sensing. The current design only contains one position sensing device, though other means of position sensing were being investigated as redundancy checks to the magnetostrictive device.

For both the SP-100 design and the Prometheus design there are twelve separate reflectors, each with its own .CDM. The CDM leadscrew is connected to a driveline, which is in tum connected to the sliding reflector, Figure 7. Because of expansion and distortion of the various components during heat up, it is expected that the CDM axis will not line up perfectly with the reflector axis during operation. Therefore, it is necessary to use flexible joints on both ends of the driveline to ensure that there is no binding caused by misaligned parts. These joints not only need to push and pull the reflector, but they also need to transmit torque without loss of motion, which could lead to uncertainty in the reflector position. The SP-100 project used a splined ball in socket joint for this purpose; while the Prometheus design proposed a dual flexure joint. The joint is shown as Figure 8. There are two flexure joints labeled "flex hinge" that provide small amounts of motion. With these flex hinges at perpendicular angles to one another, a full range of motion can be achieved. The main advantage of the dual flexure joint is its ease of fabrication. While the splined ball in socket joint would be costly and time consuming to fabricate, the dual flexure joint can be machined from a solid bar of material. Another concern of the SP-100 design is that there could be some loss of motion associated with the splines in the ball in socket.

Though both the SP-100 and the Prometheus designs were set to use stepper motors to tum the leadscrew, there was to be small differences in the internal design of the motors. When the SP. 100 CDM's were tested at the operating temperature of $800 \mathrm{~K}$, the motor experienced some binding and interference problems associated with the differences in coefficients of expansion and temperature gradients across the parts. To avoid interference in the motors, the Prometheus design was to have a larger clearance between the rotor and stator. An increase in clearance will require larger teeth on the rotor and larger step size than is possible with a smaller clearance; however, it was determined that an acceptable step size could be easily achieved while still leaving enough clearance such that binding should not be a problem.

The final difference between the SP-100. design and the Prometheus design is the axial order of the ball nut and motor. The primary purpose of the ball nut is to provide a rolling surface for the ball screw to move across. The ball nut allows the lead screw to turn through it, while intemal bearing balls provide a reduced rotational friction. Because the ball nut is more radiation tolerant than the motor, it was decided that the ball nut should be located between the shield and the 
motor. With this configuration, the ball nut acts as a shielding device to reduce the direct radiation exposure of the motor and adds distance between the shield and the motor which further reduces the amount of radiation seen by the motor.

Reference for the Project Prometheus CDA Description:

21. Personal communication and input, D. Vennetti with R. V. Richardson, MER Activity, Mechanism Test Program, 7 November 2005.

\subsection{Materials by Component}

\subsubsection{SP-100 Materials for the SRDA and the RCDA}

The design of the CDM for Project Prometheus never progressed to the extent that materials for the individual components were investigated past what was documented by the SNAP and SP100 Programs. The materials that were identified for the SP-100 Program SRDA, RCDA and DFCDA are listed below with additional information provided for each of the materials. Alternative materials are identified when possible.

Table 4 lists the common materials for the SP-100 SRDA and the RCDA and provides specific information for each of the materials. Table 5 lists the materials that were specific to the SP-100 SRDA and provides information for each, and Table 6 lists the materials specific for the SP-100 RCDA and provides information for each. Due to the length of these tables, they are broken over a number of pages.

\begin{tabular}{|c|c|}
\hline Part \& Material & Information \\
\hline \multicolumn{2}{|l|}{ Coil } \\
\hline $\begin{array}{l}\text { Magnet Wire } \\
\text { - Insulated Wire }\end{array}$ & $\begin{array}{l}\text { - Supplier. No supplier could be identified. } \\
\text { - Description: Stainless steel clad copper with ceramic } \\
\text { insulation } \\
\text { - } \text { Availability: N/A } \\
\text { - Max Operating Temp. } 700^{\circ} \mathrm{C} \\
\text { - Connections must be welded } \\
\text { - Insulation prevents small radius of curvature bend and } \\
\text { results in larger motors. }\end{array}$ \\
\hline $\begin{array}{l}\text { Bobbin } \\
- \text { MACOR }^{\mathrm{TM}}\end{array}$ & $\begin{array}{l}\text { Supplier: Morgan Technical Ceramics, (973)-227-8877, } \\
\text { http://www.morgantechnicalceramics.com and Astro Met, } \\
\text { Inc., } 513-772-1242, \text { http://www.astromet.com } \\
\text { Description: } \mathrm{SiO}_{2}=46.00 \%, \mathrm{MgO}=17.00 \%, \\
\mathrm{Al}_{2} \mathrm{O}_{3}=16.00 \%, \mathrm{~K}_{2} \mathrm{O}=10.00 \%, \mathrm{~B}_{2} \mathrm{O}_{3}=7.00 \%, \mathrm{~F}=4.00 \% \text {. } \\
\text { Availability: Both Morgan Technical Ceramics and Astro } \\
\text { Met Inc. have MACOR available for purchase in sheet, } \\
\text { bar and rod form. Astro Met Inc. has MACOR in disk } \\
\text { fom available. } \\
\text { Machinable glass ceramic, mica crystals embedded in a } \\
\text { glass matrix. }\end{array}$ \\
\hline
\end{tabular}




\begin{tabular}{|c|c|}
\hline & $\begin{array}{l}\text { Under no load it is capable of temperatures up to } 900^{\circ} \mathrm{C} \\
\text { without decomposing. }\end{array}$ \\
\hline \multicolumn{2}{|l|}{ Potting } \\
\hline - CERAMACAST 584 & $\begin{array}{l}\text { Supplier: Aremco, (845)-268-0039, } \\
\text { http://mww.aremco.com } \\
\text { - Description: } \mathrm{MgO} \text { based, with } \mathrm{Al}_{2} \mathrm{O}_{3} \text { minor component, } \\
\text { composition is proprietary } \\
\text { - Availability: Available in pint size to } 5 \text {-gallon size kits } \\
\text { - Resists temps. Up to } 1538^{\circ} \mathrm{C} \text {. } \\
\text { - Preparation requires two separate bake outs at } 100^{\circ} \mathrm{C} \\
\text { and } 120^{\circ} \mathrm{C} \text {. }\end{array}$ \\
\hline - ALCAL & $\begin{array}{l}\text { - Supplier. California Fine Wire, (805)-489-5144, } \\
\text { http://www.calfinewire.com } \\
\text { - Description: Mostly } \mathrm{SiO}_{3}, \mathrm{Al}_{2} \mathrm{O}_{3} \text { with } \mathrm{Si} \text { containing } \\
\text { organic binder, all other composition information is } \\
\text { proprietary } \\
\text { - Availability: Orders typically take } 4-5 \text { weeks } \\
\text { - Voltage rating: } 600 \mathrm{VDC} \\
\text { - } \quad \text { Service life exceeds } 5000 \mathrm{hrs} @ 426^{\circ} \mathrm{C}, 2500 \mathrm{hrs} @ \\
537^{\circ} \mathrm{C} \text {, and } 1000 \mathrm{hrs} @ 871^{\circ} \mathrm{C} \\
\text { - Can be applied to nickel-chrome alloys \& stainless } \\
\text { steels. }\end{array}$ \\
\hline - TECSIL & $\begin{array}{l}\text { Supplier: Intec, Inc., (714)-630-9192, } \\
\text { http://www.intecproductsinc.com } \\
\text { Description: } 96.00 \% \mathrm{SiO}_{3} \text {, with } \mathrm{Na}, \mathrm{Al} \text {, and } \mathrm{B} \text { oxides } \\
\text { making up other } 4.00 \% \text {. } \\
\text { - Availability: Tape and rope of any length and width is } \\
\text { usually available, if out of stock tapes and rope is back in } \\
\text { stock within about two weeks. } \\
\text { - Retains strength \& flexibility up to } 982^{\circ} \mathrm{C}\end{array}$ \\
\hline Magnetic Materials & \\
\hline $\begin{array}{l}\text { Lamination } \\
\text { - HIPERCO Sheet }\end{array}$ & $\begin{array}{l}\text { - Supplier: Carpenter Technology Corp., } \\
\text { http://www.cartech.com } \\
\text { - Description: Iron-Cobalt proprietary alloys } \\
\text { - Availability: Available in Hiperco-27 ( } 27 \% \mathrm{Co}) \text {, and } \\
\text { Hiperco-50 series that has Vanadium added ( } 48.75 \% \\
\text { Co). } \\
\text { - Different Hiperco alloys trade mechanical properties } \\
\text { verses magnetic properties. } \\
\text { - Soft magnetic alloys with high Curie temperature, } \\
\text { - } 1700^{\circ} \mathrm{F}\left(1200 \mathrm{~K}, 930^{\circ} \mathrm{C}\right) \\
\text { - Used in aerospace motors, generator laminations, } \\
\text { electromagnets, transformers and magnetic bearings }\end{array}$ \\
\hline
\end{tabular}




\begin{tabular}{|c|c|}
\hline $\begin{array}{l}\text { Machine Magnetic Flux Path } \\
\text { Structures } \\
\text { - HIPERCO Bar }\end{array}$ & See HIPERCO Sheet \\
\hline $\begin{array}{c}\text { Brake \& Clutch Faces } \\
\text { - Titanium Alloy }\end{array}$ & $\begin{array}{l}\text { - Supplier: Principal Metals, } 978-688-9800, \\
\text { http://muw.principalmetals.com } \\
\text { - Description: Various titanium alloys exist (Commercially } \\
\text { pure alloys, alpha alloys, alpha-beta alloys, and beta } \\
\text { alloys). } \\
\text { - Availability: Strip, sheet, foil, plate, bar, pipe, tube, and } \\
\text { forgings are available online. } \\
\text { - High strength to weight ratio. } \\
\text { - Excellent corrosion resistance. } \\
\text { - Hard, smooth surface that limits adhesion of foreign } \\
\text { materials. } \\
\text { - High cost compared to a lot of alloys. }\end{array}$ \\
\hline - High Nickel Alloy & See Springs Below \\
\hline$\frac{\text { Gears }}{\text { - Titanium Alloy }}$ & See Brake \& Clutch Faces Above \\
\hline $\begin{array}{c}\text { Ball Crew and Ball Nut } \\
\text { - Inconel } 718\end{array}$ & See Springs Below \\
\hline$\frac{\text { Balls for Ball Screw and Bail Nut }}{\text { - Tungsten Carbide }}$ & $\begin{array}{l}\text { - Supplier:Hoover Precision, }(770)-889-9223 \text {, } \\
\text { http://www.hooverprecision.com } \\
\text { - } \quad \text { Description: WC }=94.00 \%, C 0=6.00 \% \\
\text { - } \text { Availability: } 2.4 \mathrm{~mm}-63.5 \mathrm{~mm} \text { diameter bearings available } \\
\text { in various grades. } \\
\text { - } 92 \text { Rockwell hardness } \\
\text { - } \quad \text { Melts at } 2879^{\circ} \mathrm{C} \\
\text { - Grade } \mathrm{C}-1 \text { has better shock resistance than grade } \mathrm{C}-2 \text {, it } \\
\text { is typically used as a mining grade where toughness and } \\
\text { abrasion resistance are important, also used as a } \\
\text { bearing material. } \\
\text { - Grade C-2 has higher wear resistance and toughness } \\
\text { than grade C-1, often used as a general purpose grade } \\
\text { for pumps and valves. }\end{array}$ \\
\hline$\frac{\text { Structure }}{\text { - C-C Composite }}$ & $\begin{array}{l}\text { Supplier: Fiber Materials Inc. } \\
\text { (http://www.fibermaterials.com) and } \\
\text { ATK (http://www.atk.com) - ATK purchased Hercules, } \\
\text { Inc. in } 1995 \\
\text { - Description: Highly-ordered graphite fibers embedded in } \\
\text { a carbon matrix. } \\
\text { - Availability: depends on component } \\
\text { - Stronger, stiffer and lighter than steel or other metal. }\end{array}$ \\
\hline
\end{tabular}




\begin{tabular}{|c|c|}
\hline & $\begin{array}{l}\text { - In non-oxidizing environments retains mechanical } \\
\text { properties up to } \sim 3000^{\circ} \mathrm{C} \text {. } \\
\text { - Low thermal expansion coefficient } \\
\text { - Resistant to thermal shock } \\
\text { - Usually coated with } \mathrm{SiC} \text { to prevent oxidizing. }\end{array}$ \\
\hline - Titanium Alloy & See Brake and Clutch Faces Above \\
\hline $\begin{array}{l}\text { Hardening Coating } \\
\text { - Titanium Nitride }\end{array}$ & $\begin{array}{l}\text { - Supplier: Brycoat Inc., 1-800-989-8788, } \\
\text { http://www.brycoat.com, AND Reade Advanced } \\
\text { Materials, } 401-433-7000, \underline{\text { http: } / / \text { www.reade.com }} \\
\text { - Description: Ti=77.0 min, } \mathrm{N}=20.0 \mathrm{~min}, \mathrm{C}=0.1 \mathrm{ma} \text { (wt\%). } \\
\text { - } \quad \text { Availability: Brycoat can be contacted to determine their } \\
\text { schedule to performing coatings, and Reade Advanced } \\
\text { Materials has TiN in powder form available for purchase. } \\
\text { - Extreme hardness (harder than carbide). } \\
\text { - Highly wear resistant. } \\
\text { - Decreases friction. } \\
\text { - - Resists corrosion. } \\
\text { - Withstands high temperatures, though can begin to } \\
\text { - Typically applied via PVD. }\end{array}$ \\
\hline $\begin{array}{l}\text { Dry Film Lubricant/Anti-Seize } \\
\text { - } \text { MoS }_{2}-\text { Molybdenum } \\
\text { Disulfide } \\
\text { - } \\
\text { (Altemate material } \mathrm{WS}_{2}- \\
\text { Tungsten Disulfide }\end{array}$ & $\begin{array}{l}\text { - } \mathrm{MoS}_{2} \text { Supplier: Ionbond LLC, (248)-398-9100, } \\
\text { http://mww.ionbond.com, AND Dynamic Coatings, Inc. 1- } \\
\text { 800-396-6363, http://www.dynamiccoatingsinc.com . } \\
\text { - } \mathrm{WS}_{2} \text { Supplier. Brycoat, 1-800-989-8788, } \\
\text { http://mww.brycoat.com } \\
\text { - Description: MoS }{ }_{2} \text { deposited via PVD and CVD. WS } \\
\text { deposited via PVD. } \\
\text { - } \quad \text { Availability: Small orders take usually } 5 \text { to } 7 \text { days. } \\
\text { - } \mathrm{MoS}_{2} \text { decomposes in air, but very stable in vacuum, high } \\
\text { temperature }-1100^{\circ} \mathrm{C} \text { stability in vacuum, dry lubricant. } \\
\text { - } \mathrm{WS}_{2} \text { is stable in air up to } 500^{\circ} \mathrm{C} \text {, but is stable in vacuum } \\
\text { up to } 1250^{\circ} \mathrm{C}\end{array}$ \\
\hline$\frac{\text { Fasteners }}{\text { - Inconel or Stainless Steel }}$ & $\begin{array}{l}\text { See Springs Below for Inconel, Stainless Steel grades/alloys are } \\
\text { readily available, common materials. }\end{array}$ \\
\hline $\begin{array}{l}\text { Springs } \\
\bullet \quad \text { RENE'41 }\end{array}$ & $\begin{array}{l}\text { Supplier: Metals Unlimited, 1-800-782-7867, } \\
\text { http://www.metals-unlimited.com AND Spring Engineers } \\
\text { of Houston LTD, 1-800-899-9488 } \\
\text { http://wwww.springhouston.com } \\
\text { - Description: } \mathrm{Cr}=18.00-20.00 \%, \mathrm{Ni}=\text { remainder, } \mathrm{Mo}=9.00 \\
10.50 \%, \mathrm{Co}=10.00-12.00 \%, \mathrm{Al}=1.4-1.8 \%, \mathrm{Ti}=3.00- \\
3.30 \%, \mathrm{Fe}=5.00 \% \text { max., plus other minor impurities. } \\
\text { - Availability: Metals Unlimited has sheet and plate in }\end{array}$ \\
\hline
\end{tabular}




\begin{tabular}{|c|c|}
\hline & $\begin{array}{l}\text { stock. Spring Engineers have access to RENE' } 41 \text { for } \\
\text { spring manufacture, though extended lead times can } \\
\text { sometimes be encountered. } \\
\text { - A wrought nickel based high temperature, high strength } \\
\text { alloy. } \\
\text { - Good oxidation resistance at high temperatures in the } \\
\text { range of } 1200-1800^{\circ} \mathrm{F}\left(649-982^{\circ} \mathrm{C}\right) \text {. } \\
\text { - Conventional machining techniques used for iron based } \\
\text { alloys may be used. } \\
\text { - Commonly used welding methods work well with this } \\
\text { alloy - matching alloy filler metal should be used. }\end{array}$ \\
\hline - Inconel 750 \& Inconel 718 & $\begin{array}{l}\text { - Inconels are well known, readily available, high-strength } \\
\text { austenitic nickel-chromium-iron alloys that are resistant } \\
\text { to corrosion and oxidation and have good heat resistant } \\
\text { properties. } \\
\text { - Inconel } x-750 \text { and } 718 \text { are used in gas turbines, jet } \\
\text { engines, nuclear power plants and heat treating } \\
\text { furnaces. }\end{array}$ \\
\hline$\frac{\text { Bearings }}{\bullet \quad \text { Stellite }}$ & $\begin{array}{l}\text { See Section 3.2.3.1 entitled "CDA Material Development Issues, } \\
\text { SP-100 Control Drive Assemblies - Lessons Learned" }\end{array}$ \\
\hline - Silicon Nitride & $\begin{array}{l}\text { See Section 3.2.3.1 entitled "CDA Material Development Issues, } \\
\text { SP-100 Control Drive Assemblies - Lessons Leamed" }\end{array}$ \\
\hline
\end{tabular}

Table 4: Description of Common Materials for the SP-100 SRDA and RCDA

\begin{tabular}{|c|c|}
\hline Part \& Material & Information \\
\hline $\begin{array}{l}\text { Safety Rod Tubular Structure } \\
\text { - PWC-11 }\end{array}$ & $\begin{array}{l}\text { - Supplier: No supplier could be identified. } \\
\text { - Description: } \mathrm{Nb}-1 \mathrm{Zr}-0.06 \mathrm{C} \\
\text { - Availability: Not in production, would need to investigate } \\
\text { companies to make. } \\
\text { - Some evidence of phase instability during long-term } \\
\text { thermal exposures. } \\
\text { - Aging the PWC-11 material for } 1000 \mathrm{~h} \text { at } 1970{ }^{\circ} \mathrm{F}(1077 \\
\left.{ }^{\circ} \mathrm{C}\right) \text { prior to low stress creep testing does not appear to } \\
\text { affect the long term (>28,000 h) strength. } \\
\text { - In annealed state is more creep resistant than a similarly } \\
\text { annealed } \mathrm{Nb}-1 \mathrm{Zr} \text { alloy by at least a factor of } 3 \text { in applied } \\
\text { stress. }\end{array}$ \\
\hline $\begin{array}{l}\text { - Nb-1Zr (Niobium 1\% } \\
\text { Zirconium) }\end{array}$ & $\begin{array}{l}\text { Supplier. Cabot Corporation, 610-367-1500, } \\
\text { http://w1.cabot-corp.com } \\
\text { Description: } 98.5 \mathrm{Nb} \min , 0.8-1.2 \mathrm{Zr}, 0.0100 \mathrm{C} \max \\
0.0300 \mathrm{~N} \max , 0.0300 \mathrm{O} \max , 0.0020 \mathrm{H} \max , 0.01 \mathrm{Hf} \\
\max , 0.01 \mathrm{Fe} \max , 0.005 \mathrm{Mo} \max , 0.005 \mathrm{Ni} \max , 0.005 \\
\text { Si max, 0.2 Ta max, } 0.05 \mathrm{~W} \max \\
\text { - Availability: Foil, sheet, plate, wire, rod, billet, tube, and }\end{array}$ \\
\hline
\end{tabular}




\begin{tabular}{|c|c|}
\hline & $\begin{array}{l}\text { powder in stock. } \\
\text { - Rated tensile and yield strength up to } 3000^{\circ} \mathrm{F}\left(1650^{\circ} \mathrm{C}\right) \\
\text { - Low strength. } \\
\text { - Easily machined. } \\
\text { - Can be joined by electron beam welding, resistance } \\
\text { welding, and gas tungsten arc welding. } \\
\text { - Oxidize rapidly at elevated temperatures, even in } \\
\text { - } \text { atmospheres containing very low oxygen concentrations. } \\
\text { - } \text { thermal neutron capture cross - section. }\end{array}$ \\
\hline$\frac{\text { Slider Bearing Surfaces }}{-\mathrm{ZrC}}$ & $\begin{array}{l}\text { - Supplier: Goodfellow Corporation, 1-800-821-2870, } \\
\text { Email: info@goodfellow.com } \\
\text { - } \quad \text { Description: Zirconium Carbide } \\
\text { - } \quad \text { Availability: Compound powder form in stock. } \\
\text { - Characterized by: High hardness, high melting point, high } \\
\text { electrical conductivity, and high strength. } \\
\text { - } \quad \text { Limited use because there is no commercially viable } \\
\text { - } \quad \text { sintering process. } \\
\text { - } \quad \text { Hot pressing of powders between } 3452^{\circ} \mathrm{F}\left(1900^{\circ} \mathrm{C}\right) \text { and } \\
4172^{\circ} \mathrm{F}\left(2300^{\circ} \mathrm{C}\right) \text { can achieve densities of greater than } \\
93 \% \text {. } \\
\text { - Coatings of ZrC can be deposited by PVD and CVD. } \\
\text { - Limited use in oxidizing environments. } \\
\text { - ZrC is good for ultra high temperature applications } \\
\text { because of its high melting point } 5882^{\circ} \mathrm{F}\left(3250^{\circ} \mathrm{C}\right) \text {, good } \\
\text { thermal shock resistance and absence of phase changes } \\
\text { in the solid state. }\end{array}$ \\
\hline - $\mathrm{HfC}$ & $\begin{array}{l}\text { - Supplier: Atlantic Equipment Engineers, 1-800-486-2436, } \\
\text { http://www.micronmetals.com/hafnium carbide.htm } \\
\text { - Description: Hafnium Carbide } \\
\text { - Availability: Powder form in stock. } \\
\text { - The most refractory binary compound known to man. } \\
\text { - Used in hard coatings, often applied by processes such } \\
\text { as plasma spraying. }\end{array}$ \\
\hline$\frac{\text { Reactor Vessel Thimble Interface }}{\text { - Carbide Coated } \mathrm{Nb}-1 \mathrm{Zr}}$ & See Safety Rod Tubular Structure and Slider Bearing Surfaces \\
\hline - Mo-41Re & $\begin{array}{l}\text { - Supplier: Rhenium Alloys, Inc. 1-888-RHENIUM, Email: } \\
\text { info@rhenium.com } \\
\text { - Description: Molybdenum with 41\% Rhenium } \\
\text { - Availability: Rod, bar, foil, sheet, and plate form in stock. } \\
\text { - Good fabricability, liquid-metal corrosion resistance, and } \\
\text { resistance to low-pressure oxygen. }\end{array}$ \\
\hline
\end{tabular}




\begin{tabular}{|c|c|}
\hline & $\begin{array}{l}\text { - Low thermal conductivity. } \\
\text { - Unlikely to precipitate potentially undesirable phases. } \\
\text { - Oxidation resistance is better than } \mathrm{Nb}-1 \mathrm{Zr} \text {. } \\
\text { - Oxidation of Mo-41Re does cause thinning. }\end{array}$ \\
\hline$\frac{\text { Nuclear Poison }}{\text { - Boron Carbide }}$ & $\begin{array}{l}\text { - Supplier. Goodfellow Corporation, 1-800-821-2870, } \\
\text { Email: info@goodfellow.com } \\
\text { - Description: } \mathrm{B}_{4} \mathrm{C} \\
\text { - } \text { Availability: Sheets, rod, and sputtering targets in stock. } \\
\text { - One of the hardest materials known }\left(3^{\text {rd }} \text { behind diamond }\right. \\
\text { and cubic boron nitride). } \\
\text { - Difficult to sinter to full density. } \\
\text { - With hot pressing or sinter HIP is required to achieve } \\
\text { - } \text { greater than } 95 \% \text { of theoretical density. } \\
\text { - Good chemical resistance. } \\
\text { - } \text { Low Density. }\end{array}$ \\
\hline$\frac{\text { Nuclear Poison to Clad Barrier }}{\text { - Mo Foil }}$ & $\begin{array}{l}\text { - Supplier: SPI supplies, } \\
\text { http://www.2spi.com/catalog/standards/molybdenum- } \\
\text { moly-foil.shtmi } \\
\text { - Description: Molybdenum Foil } \\
\text { - Availability: Foil in } 0.05 \mathrm{~mm} \text { thickness in stock. } \\
\text { - Low thermal expansion and thermal conductivity is twice } \\
\text { that of iron. } \\
\text { - Good electrical conductivity. } \\
\text { - Serviceable to temperatures } ~ \\
\text { oxidizing conditions. } \\
\text { - Oxidizes at temperatures above } 1400^{\circ} \mathrm{F}\left(1100^{\circ} \mathrm{C}\right) \text { in non- }\left(760^{\circ} \mathrm{C}\right) \text { in air, } \\
\text { the oxide layer sublimes and the base metal is attacked. }\end{array}$ \\
\hline $\begin{array}{l}\text { Nuclear Moderator/Reflector } \\
\text { - Beryllium Oxide }\end{array}$ & $\begin{array}{l}\text { - Supplier: Goodfellow Corp., 1-800-821-2870, Email: } \\
\text { info@goodfellow.com } \\
\text { - Description: BeO } \\
\text { - Availability: A variety of sheets and rods in stock. } \\
\text { - Excellent electrical insulating properties and high thermal } \\
\text { conductivity. } \\
\text { - Corrosion resistant. } \\
\text { - Due to toxicity of powder when inhaled, BeO is one of the } \\
\text { most expensive raw materials to work with. } \\
\text { - Low neutron-capture cross section and high neutron } \\
\text { moderating ability. } \\
\text { - Apart from reactivity with water vapor at high temp } 1832 \\
{ }^{\circ} \mathrm{F}\left(1000^{\circ} \mathrm{C}\right) \text {, it is one of the most chemically stable } \\
\text { oxides, resisting both carbon reduction and molten metal }\end{array}$ \\
\hline
\end{tabular}




\begin{tabular}{|c|c|}
\hline & attack at high temperature. \\
\hline $\begin{array}{l}\text { Shielding Follower Section } \\
\text { - Filled w/ Shield Materials } \\
\text { Comparable to Flight Shield } \\
\text { at Same Station Position }\end{array}$ & NA \\
\hline$\frac{\text { Support/Spacer Structure within S.R. }}{\text { - Titanium Honeycomb }}$ & $\begin{array}{l}\text { - Supplier: Benecor, Inc, 316-682-6244, } \\
\text { http://www. benecorinc.com } \\
\text { - Description: Honeycomb formed Titanium, usually ASTM } \\
\text { B265 Grade 9. } \\
\text { - Availability: Thicknesses from } 0.001^{\prime \prime}-0.010^{\prime \prime} \text {, cell sizes } \\
\text { from } 1 / 8^{\prime \prime} \text { to } 1^{\prime \prime} \text { along with a variety of cell configurations } \\
\text { available for custom fabrication. } \\
\text { - No structural degradation was detected after } 50 \text { cycles } \\
\text { from room temperature to } 900^{\circ} \mathrm{F}\left(482^{\circ} \mathrm{C}\right) \text {. } \\
\text { - Very high strength to weight ratio. } \\
\text { - Some forms are flexible. }\end{array}$ \\
\hline Safety Latch & \\
\hline $\begin{array}{l}\text { Lock Bars } \\
\qquad \begin{aligned} \text { - } & \text { PWC-11 } \\
\text { - } & \mathrm{Nb}-1 \mathrm{Zr}\end{aligned}\end{array}$ & See Safety Rod Tubular Structure \\
\hline $\begin{array}{l}\text { Spring } \\
\text { - ASTAR 811C }\end{array}$ & $\begin{array}{l}\text { - Supplier: Wah Chang, } 541-926-4211 \text {, } \\
\text { http://www.wahchang.com } \\
\text { - Description: Ta }-8 \mathrm{~W}-1 \mathrm{Hf}-0.7 \mathrm{Re}-0.025 \mathrm{C} \\
\text { - Availability: Not in production, could be made under } \\
\text { special order. } \\
\text { - Promising for high temperature applications because of } \\
\text { its high melting temperature, high strength, and good } \\
\text { weldability, fabricability, and ductility. } \\
\text { - Well developed: }>70 \text { tests, }>250,000 \text { hours, longest } \\
\text { individual test } ~ 24,000 \text { hours. } \\
\text { - Long-term stability at elevated temperatures is uncertain. }\end{array}$ \\
\hline $\begin{array}{l}\text { Latch Housing } \\
\begin{aligned} & \text { - } \text { PWC-11 } \\
& \text { - } \mathrm{Nb}-1 \mathrm{Zr} \\
&\end{aligned}\end{array}$ & See Safety Rod Tubular Structure Above \\
\hline $\begin{array}{l}\text { Latch Assembly Alignment Pins } \\
\text { - ASTAR 811C }\end{array}$ & See Spring Above \\
\hline $\begin{array}{l}\text { Contact/Guidance Surfaces } \\
\text { - } \mathrm{ZrC} \\
\text { - } \mathrm{HfC}\end{array}$ & See Slider Bearing Surface Above \\
\hline \multicolumn{2}{|l|}{ Separation Joints } \\
\hline Springs In/Aft Flight Shield \& & \\
\hline
\end{tabular}




\begin{tabular}{|c|c|}
\hline $\begin{array}{l}\text { Structural Components } \\
\text { - } \quad \text { RENE'41 } \\
\text { - Inconel } 750 \\
\text { - Inconel } 718\end{array}$ & See Springs, Table 4 \\
\hline $\begin{array}{l}\text { Coatings } \\
-\quad \text { Nitride }\end{array}$ & $\begin{array}{l}\text { - Supplier: Variety of suppliers depending on specific } \\
\text { nitride used. } \\
\text { - } \\
\left.\text { - Si3N4, AIN, Sialon-Mixture of } \mathrm{SiN}, \mathrm{SiO}_{2}, \mathrm{Al}_{2} \mathrm{O}_{3}, \text { and } \mathrm{AIN}\right) \text {. } \\
\text { - } \text { Availability: Most nitrides available and in stock. } \\
\text { - Extremely hard materials. } \\
\text { - Used to improve surface properties of the substrate. } \\
\text { - Usually applied by active growth or } \mathrm{PVD} \text {. } \\
\text { - Maximum operating temperature of some nitrides } \\
\text { exceeds } 3000^{\circ} \mathrm{F}\left(1650^{\circ} \mathrm{C}\right) \text {. }\end{array}$ \\
\hline $\begin{array}{l}\text { Lubricant/Anti-Seize } \\
\text { - } \mathrm{MoS}_{2}\end{array}$ & See Dry Film Lubricant/Anti-Seize, Table 4 \\
\hline
\end{tabular}

Table 5: Description of Materials Specific for the SP-100 SRDA

\begin{tabular}{|c|c|}
\hline \multirow{2}{*}{\multicolumn{2}{|c|}{$\begin{array}{l}\text { Part \& Material } \\
\text { Reflector Guide/Positioning }\end{array}$}} \\
\hline & \\
\hline $\begin{array}{l}\text { Guide Rods } \\
\text { - C-C Composite }\end{array}$ & See Structure, Table 4 \\
\hline - Ta-10W & $\begin{array}{l}\text { - Supplier: Cabot Corporation, } 610-367-1500, \\
\text { http://w1.cabot-corp.com } \\
\text { - } \quad \text { Description: } 90 \% \text { Tantalum, } 10 \% \text { Tungsten } \\
\text { - } \quad \text { Availability: Foil, sheet, plate, wire, rod, billet, tube, and } \\
\text { powder in stock or can be obtained with minimal lead } \\
\text { time. } \\
\text { - Excellent for high temperature applications (up to } \\
4500^{\circ} \mathrm{F} \text { ). } \\
\text { - High strength (twice the tensile strength of pure } \\
\text { tantalum). } \\
\text { - } \text { Most corrosion resistant refractory metal. } \\
\text { - } \text { Fairly high ductility. } \\
\text { - High thermal conductivity }\end{array}$ \\
\hline $\begin{array}{l}\text { Guide Rod Surface Coating } \\
-\quad \mathrm{Al}_{2} \mathrm{O}_{3} \text { (for Ta-10W) }\end{array}$ & $\begin{array}{l}\text { Supplier. lonbond, } 416-918-6565 \text {, } \\
\text { http://mww.ionbond.com } \\
\text { - Description: CVD deposited } \mathrm{Al}_{2} \mathrm{O}_{3} \\
\text { - } \quad \text { Availability: Depends on coating thickness and batch } \\
\text { size, significant lead times may be necessary. } \\
\text { - Melts at } 2045^{\circ} \mathrm{C}\end{array}$ \\
\hline
\end{tabular}


B-MT(AMSI)-43

Page 28

\begin{tabular}{|c|c|}
\hline & $\begin{array}{l}\text { - Differences in thermal expansion between } \mathrm{Al}_{2} \mathrm{O}_{3} \text { and } \mathrm{Ta}- \\
10 \mathrm{~W} \text { might lead to cracking in } \mathrm{Al}_{2} \mathrm{O}_{3} \text { coating. }\end{array}$ \\
\hline $\begin{array}{l}\text { Self-Aligning Guide Bearing Insert } \\
\text { - P-5 Carbon-Graphite }\end{array}$ & $\begin{array}{l}\text { - Supplier: Morgan AM\&T (http://wuw.mamat.com) } \\
\text { - Description: Morgan AM\&T provides a range Carbon- } \\
\text { Graphites for bearings, seal rings, rotary vane } \\
\text { compressors, etc. } \\
\text { - P-5 is a grade of Carbon-Graphite used for bearings. } \\
\text { - P-5 temperature limitation is } \sim 316^{\circ} \mathrm{C} \\
\text { - Carbon-Graphite P- } 3310 \text { is a for high-temperature } \\
\text { bearing useup to } 538^{\circ} \mathrm{C} \text {. }\end{array}$ \\
\hline $\begin{array}{r}\text { Bearing Insert Housing } \\
\text { - C-C Composite } \\
\text { - Ta-10W } \\
\end{array}$ & See Guide Rods Above \\
\hline $\begin{array}{l}\text { Bearing Insert Housing Surface } \\
\text { Coating } \\
\qquad \mathrm{Al}_{2} \mathrm{O}_{3} \text { (for Ta-10W) }\end{array}$ & See Guide Rod Surface Coatings Above \\
\hline $\begin{array}{l}\text { Structural Brackets/Supports } \\
\text { - } \mathrm{Nb}-1 \mathrm{Zr}\end{array}$ & See Safety Rod Tubular Structure, Table 5 \\
\hline $\begin{array}{l}\text { Fasteners } \\
\text { - Ta-10W }\end{array}$ & See Guide Rods Above \\
\hline $\begin{array}{l}\text { Push Rods } \\
\text { - Ta-10W }\end{array}$ & See Guide Rods Above \\
\hline $\begin{array}{c}\text { Push Rod Bearings/Articulation Joint } \\
\text { - Same as Guide Bearing }\end{array}$ & NA \\
\hline
\end{tabular}

Table 6: Description of Materials Specific for the SP-100 RCDA

\subsubsection{Materials For Project Prometheus CDM}

The design of the Control Drive Mechanism for Project Prometheus was based upon the SP-100 CDA design, but with the following proposed modifications that would require the identification of the appropriate material:

- The incorporation of a hysteresis brake verses an electromagnetic brake (hollow shaft brake).

- A magnetostrictive transducer to sense the leadscrew position, consisting of a transducer, a guide wire, and a magnet.

- A dual flexure joint instead of the SP-100 project splined-ball-in-socket (articulation joints).

Other identified changes for the Prometheus CDM should not impact material choices.

The description of the hysteresis brake identifies the utilization of two permanent magnets: one made of samarium/cobalt and a second an alnico magnet. The magnetostricitve transducer position indicator includes a wire and a permanent magnet. 
The original actuator design for the SNAP 10a incorporated a permanent magnet in its design. Subsequent designs eliminated the permanent magnet in the rotor because of reliability issues associated with the temperature limitations of permanent magnets. Samarium/cobalt magnets are strong permanent magnets. An example of a supplier for these magnets is Arnold Magnetic Technologies, Inc. (http://wnw.arnoldmagnetics.com). Samarium/cobalt magnets have a Curie temperature of $700-800^{\circ} \mathrm{C}$, but are limited to service that does not exceed $250-350^{\circ} \mathrm{C}$. There is an effort by this company to increase the effective service temperature to $400^{\circ} \mathrm{C}$. Another supplier of Sm-Co magnets, Electron Energy Corp. (http://www.electronenergy.com), supplies $\mathrm{Sm}_{2} \mathrm{Co}_{17}$ magnets with operating temperatures in the range of 400 to $550^{\circ} \mathrm{C}$.

Arnold Magnetic Technologies also supplies Alnico permanent magnets. Alnico is a coarsegrained material that is hard and brittle which can not be drilled or machined by conventional methods. It has excellent stability with respect to temperature changes; however, at $538^{\circ} \mathrm{C}$ it undergoes a metallurgical change that results in a rapid reduction in its magnetic strength.

The SNAP and SP-100 Programs used ball and socket with a rotating journal shaft for selfaligning to avoid binding in the control drive mechanism. Project Prometheus CDM proposed the use of dual flexure joints at either end of the drive line, Figure 8, machined from a single piece of material, most likely the same material that the drive line is made from. Based upon the SP-100 design, the materials for the drive line and flexure joints would probably be Ta-10W (Table 3), PWC-11 or Nb-1Zr (Table 2).

\subsubsection{CDA Material Development Issues}

\subsubsection{SP-100 Control Drive Assemblies - Lessons Learned}

This section is a synopsis of the material issues described in Reference 5 . When work on the SP-100 was stopped, Reference 5, entitled "SP-100 Control Drive Assemblies - Lessons Learned," was written to provide conclusions and recommendations for future CDA work. The report covered project considerations, materials development, design, fabrication and testing. This summary addresses the material-related issues.

Delivery Schedule of Uncommon Materials - Only a limited number of materials are suitable for service under the temperature and vacuum conditions that the CDA's have to operate. The SP100 Program CDA effort found that, while these materials were listed as available in the manufacture's literature, the reality was that these materials were not readily available in small quantities and on a one-time basis: the cost was high and the delivery schedule was uncertain.

Uncommon Bearing - The SP-100 CDA team investigated adapting various high-temperature ball bearings. The bearings that they investigated and found unsuitable for use under the specified operating conditions included the following:

- Silver lubricated, tool steel bearings used in x-ray tubes by General Electric Medical Systems.

- $\mathrm{MoS}_{2}$ lubricated, all Stellite 25 bearings used on gas valves of jet engines.

- High-temperature, jet engine bearings.

The program pursued the purchase of custom, high-temperature ball bearings. They found that they had a difficult time finding a manufacturer that would take on the one-time task of developing, manufacturing and delivering the bearings in a timely manner. The program believed 
that they had a viable solution, but did not believe that they covered the task exhaustively and did not have adequate testing.

Titanium Aluminide - Ti-Al alloys were identified late in the SP-100 program, and thus, the alloys were not investigated for CDA components. Ti-Al alloys are as strong as nickel-based alloys up to approximately $760^{\circ} \mathrm{C}$, are much lighter, have a high resistance to oxidation and hydrogen absorption, and have excellent creep properties. The gamma and orthorhombic phase alloys are the alloys of interest; e.g., Ti-47Al-2Cr-2Ni. It is available through READE (http://www.reade.com; 401.433.7000).

A web site article, http://www.azom.com, on titanium aluminide also identified titanium-niobium orthorhombic alloys as a future candidate for light-weight, high-strength, high-temperature applications, and as a good candidate for the matrix material for fiber-reinforced MMC's.

Stellite Star J - Stellite Star J was identified by the SP-100 Program as a good candidate for hightemperature bearing races. Because of the cost and lead time, Stellite Star $\mathrm{J}$ was not adequately tested.

Stellite is the trade name for a class of proprietary cobalt-nickel based alloys produced by Deloro Stellite Company (http://www. stellite.com). The Stellite alloys are materials that are designed to combat wear in aggressive environments. Stellite Star J composition is a maximum 3\% nickel, maximum $3 \%$ iron, $2.5 \%$ carbon, $32 \%$ chromium, $1 \%$ manganese, $0.5 \%$ silicon, $17 \%$ tungsten and the balance cobalt. It has a melting point of $2130^{\circ} \mathrm{F}(1439 \mathrm{~K})$.

On the company's web site they recommend for bearing races other alloys: Stellite 31, Stellite 6 , Stellite 6B, Stellite 3, Stellite 19, and Nistelle X, a nickel-based alloy. It is concluded that any future development work would need to work with the Deloro Stellite to determine the best alloy for the application and environment.

Silicon Nitride Ball Bearings - Tests by the SP-100 CDA team demonstrated that silicon nitride balls, lubricated with $\mathrm{MoS}_{2}$ performed well under the systems projected operating conditions for several multiples of their projected life. However, the silicon nitride balls were not tested for compatibility with races made of Stellite alloys. The silicon nitride balls were also not tested for sticking when the ball and race lubricant coating was absent.

Silicon nitride bearing balls are a well known item, covered by ASTM standard F2094-03a, and are readily available from a number of companies; e.g., NTK Technologies (http://www.ntktech.com), Saint Gobain Ceramics (http://www.cerbec.com) and Ceradyne, Inc. (http://www.ceradyne.com).

Dimensional Stability - During testing the SP-100 CDA development program experienced a number of situations of material dimensional instability at elevated temperatures; e.g., a motor frame made from Hiperco-27 that warped and Inconel springs that changed their spring rate, as well as other situations.

The CDA Development team recommended that future development efforts pay particular attention to material metallurgy and processing to be able to reliably control the dimensional stability of the components.

Bobbin Material - Ceramic bobbins were used in the SP-100 CDA test article. The material was readily available, cheap, machinable and adequate for testing; however, it was not flight 
prototypical material. The CDA development team recommended that an appropriate bobbin material be identified and tested. They suggested synthetic sapphire as a potential bobbin material that would have better mechanical and thermal properties.

Synthetic sapphire can be grown in cylindrical ingots up to $200 \mathrm{~mm}$ in diameter. It is $\mathrm{Al}_{2} \mathrm{O}_{3}$ and is one of the hardest materials. It is chemically inert, thermally stable up to $1600^{\circ} \mathrm{C}$, with a melting temperature of $2050^{\circ} \mathrm{C}$. It has numerous industrial applications in optics, electronics and for mechanical applications (e.g., tubes). It is available, for example, from Monocrystal, Inc. (http://www.monocrystal.com) and Maintechs, Inc. (http://www.maintechssapphire.com).

\subsubsection{Project Prometheus CDM Material Issues}

The Prometheus CDM conceptual design incorporated a hysteresis brake instead of an electromagnetic brake (hollow shaft brake) and a magnetostrictive transducer to sense the leadscrew position that consisted of a transducer, a guide wire, and a magnet. In both of these cases the permanent magnet material must be tested to demonstrate its reliability under the temperature and vacuum conditions that it must operate.

The Prometheus design also suggested the use of a dual flexure joints, instead of the SP-100 project splined-ball-in-socket joints, on the driveline. The materials used for the dual flexure joints must be tested to demonstrate their reliability, without failure, over the lifetime of the system.

\subsection{SUMMARY}

A survey was conducted to identify and document the materials that were used for the control drive mechanisms for the SNAP and the SP-100 space nuclear power reactor systems. The conceptual control drive mechanism for the Prometheus Project was based upon the SP-100 design. The materials for the SP-100 were listed by component. For each of the materials a survey was completed to identify a supplier and its availability. Major distinguishing characteristics for each of the materials were also listed. The survey revealed that many of the materials that were new and difficult to acquire in the 1980's and early 1990's appear to be currently more readily available. Often, these materials have evolved to where various forms, for example different alloys, have been developed to meet user requirements. These statements apply to, for example, HIPERCO and STELLITE alloys, carbon-carbon components, and ceramic materials. Operational experience has also evolved from the application of these materials under a variety of conditions.

As part of this research it was found that the SP-100 CDA development team, upon termination of the program, identified material issues that needed to be addressed prior to achieving the technology status necessary to support their mission lifetime specifications. These issues included the acquisition and delivery of uncommon materials and bearings, the development of advanced materials, the demonstration of adequate lifetime of bearings and bearing races of dissimilar materials under operating conditions, control of the metallurgy and processing of materials to ensure dimensional stability, and the choice of a material for magnet wire coil bobbins that is appropriate for the systems operating conditions. The SP-100 control rod drive assembly development team believed that at the program's termination it had demonstrated that the technology status was adequate for a 3-year operating lifetime and 5-year mission design $\left(20-\mathrm{kW}_{\mathrm{e}}\right.$ design), but had not demonstrated the technology to support a mission that required operation for seven years and a 10-year mission (the 100-kW. design). 
B-MT(AMSI)-43

Page 32

The conceptual design of the CDA for Prometheus was also addressed to identify materials issues that were associated with any of the proposed changes from the SP-100 design. The primary differences between the two designs, that would potentially impact material choices, were that the Project Prometheus proposed the use of a magnetic hysteresis brake instead of a electromagnetic brake, the use of a magnetostrictive transducer to sense the leadscrew position verses a LVDT, and the incorporation of a dual flexure joints on the reflector driveline instead of splined ball in socket joints. The major material issues related to these proposed changes were the identification of permanent magnetic materials that retained their magnetic characteristics under the specified operating conditions, and the selection and testing of the appropriate material to accommodate the design and lifetime of a dual-flexure joint.

Despite the advances in materials and the operational experience gained with these materials over the past 10 to 15 years, the testing and demonstration of a CDM in the operating conditions of a space nuclear power system is still necessary. With the evolution of materials, an assessment and identification of the best materials to meet the design requirements will be necessary when work resumes on a control drive mechanism for a space nuclear power system.

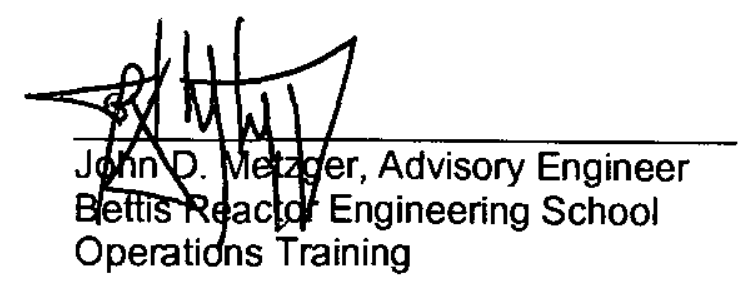

Approved by:

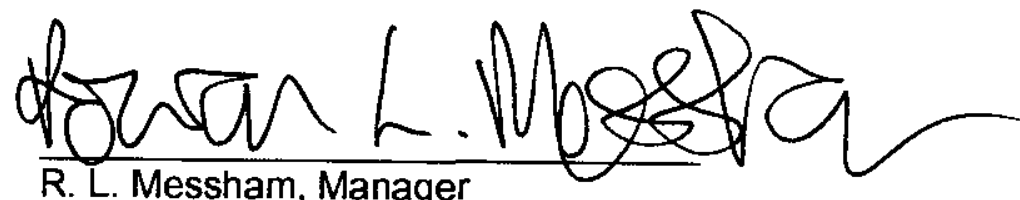

R. L. Messham, Manager

Advanced Materials System Integration

Materials Technology 


\section{CONCURRENCE RECORD SHEET}

- DOCUMENT NUMBER: B-MT(AMSI)-43

- THIS DOCUMENT CONTAINS INFORMATION WHICH SHOULD BE CONSIDERED FOR PATENT DISCLOSURES

- THIS DOCUMENT CONTAINS INFORMATION WHICH MEETS BETTIS WORK CATEGORIES [A,B,C,D or (NAA)]

CONCURRENCE SIGNATURES (Activity must be included) - RESOLVE COMMENTS BEFORE SIGNING

SIGNATUREIACTIVITY

DATE

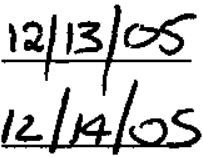

TYPE

DETAILS OF REVIEW REQUESTED (if necessary)

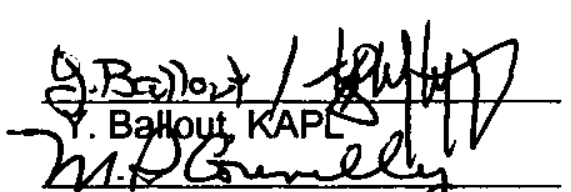

M. P. Connelly, MERO

\section{TYPE OF REVIEWS (to be determined by author) [See table at end of instructions for definitions.]}

1-Peer:Summary 2-Peer:Intermediate 3-Peer:Detail 4-Independent 5-Informal Committee 6-Formal Committee 7-Specialist 8-Interface NAME TYPED AND SIGNATURE OF NEXT HIGHER MANAGER NOT SIGNING RN LETTER

J. E. Hack, Manager, Advanced Materials Technology

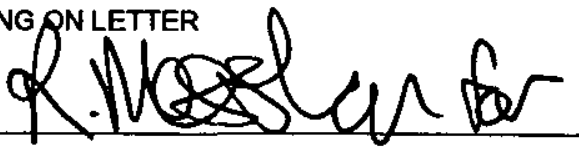

- CONTRIBUTORS AND IMPACTED PARTIES NOT REQUESTED TO CONCUR ANDWHY:

None

\section{DISTRIBUTION}

Bettis

M. N. Smith - 02B/GM

S. D. Harkness - 01Q/MT

M. J. Zka - 01C/SE

J. E. Hack - 05R/MT

R. L. Messham - 14B/MT

J. D. Metzger - 52ANOT

C. W. Clark, 01C/SE

C. D. Eshelman, 36E/SE

D. Hagerty, 38D/SE

R. C. Jewart, 01C/SE

D. G. Vennetti, COB3/REO

K. T. Koch, 16AlTO

M. P. Connelly, 38B/MER

BPMI-P

S. D. Gazarik

R. F. Hanson

BPMI-S

F. Barilla
NR

M. Natale, 081/8024

J. D. Yoxtheimer, 08\$/8034

T. H. Beckett, 08B/8012

S. Bell, 081/8024

D. 1 Curtis, 08S/8034

D. E Dei, 08A/801

T. N. Rodeheaver, 08I/8024

S. J Rodgers, 08E/8019
KAPL

S. Simonson, 92

Y. Ballout, 92

J. M Ashcroft, 132

P. F Baldasaro, 111

C. F. Dempsey, 93

K. C Loomis, 132

D. F McCoy, 111

H. Schwartzman, 132

M. J. Wollman, 111
PNR

S. C. Berasi

S. Kraynik

J. Andes

R. J Argenta

H. A Cardinali

J. F Koury

G. White

DATE

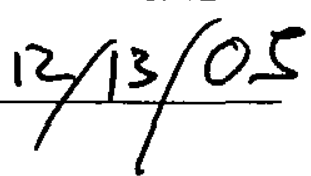

SNR

G. M. Millis, 065

D. Clapper, 065

S. Cramer, 065

W. Leahy, 065

H. Miller, 065

D. J. Potts, 065

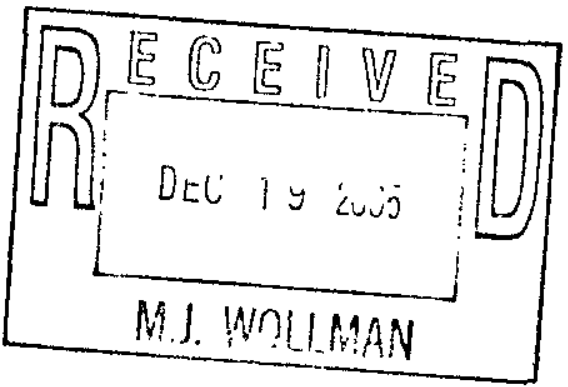

